\title{
Description Of Knowledge For Teenager Girls About Menarche At Elementary School State13 Paya Bili District Meurah Mulia North Aceh 2015
}

\section{Irwana Wahab}

\author{
\#Faculty of Public Health University of North Sumatera, Medan 20155, Indonesia
}

E-mail : irwana_wahab@yahoo.com

\begin{abstract}
The research is done for knowing how far the teenager girls knowledge about their reproductive or menarche and alsoto create the quality of family in 2015 through increased knowledge, awareness of the attitudes and behavior of the young girls become adolescents. Also to see the family care to their daughter who will have the proces of change phisical, and attitude. The girls becomes disability in control her mental healthy, function part of their body and processes reproduction. The last few years ofadolescent reproductive health issues into national concern because it was realized that youth in her face specific issues that require special attention. The young ladys needs information about the proces of reproductive. This condition, actually has the problem in our country. It is not getting special attention from their parents. The menarche to be an important thing who becomes a teen, and needs special care because it marks the beginning of adulthood, so biological woman is being developed. During this part of the community feel that problem face by their daughter no need to discuse about menstruation why it become not so familier or polite in the culture to talk about it. So, the teen inadequate knowledge about the physical and psychological changes to associate in menarche, the mental readiness is indispensable before menarche because of feelings of anxiety and fear will emerge, but it is also a privation of knowledge about self-care needed during menstruation. The aim purpose of this study is to describe the level of knowledge from the younggirl's about the menarche. This is a type of a descriptive research, the population were used the students from Elementy School State 13 Paya Bili distric Murah Mulia for a week in May, 2015. The sample took by random 30 school girls who study in the level 5 and 6 . The questionerswere distributed to collect the data. Then analize the data.Theresult showed that school girls have the knowledge about menarche. That can be catagoried $67 \%$ the adolescent girls understand and able to take a care the condition of menarche that will come to their. Eventhought, the condition is good, but there are still have $33 \%$ more of the teens need to get information about menarche and it impacts for the body changes. So that anxiety and unpreparedness may appear at menarche. It hopes for student who study at elementary school have to prepare more information about the reproductive health. The relevant knowledge or lesson on reproductive health should be given the information. So, young women can face menarche with quiet and confident.
\end{abstract}

Keywords: Knowledge, Teenager about Menarche

\section{INTRODUCTION}

The teenager girls who will have a reproductivehealth to create quality family in 2015 through increased knowledge, awareness of the attitudes and behavior of the girls become adolescents. So the parents care, and responsiblelity to the member of family life, as well as providing services to their littel girl become an adolescents. They will have special problems, and her family have knowledge, awareness of reproductive health attitudes, behavior, and make them ready to resposible for a quality family. Allofthe young people need information about the changes thier reproductive health in order to improve human resources teenager (Widyastuti, et al, 2009).

Adolescent reproductive health is not only free of sickness and disability, but also mental healthy, social aspects of tools, systems, functions and processes reproduction itself (BKKBN, 2011).

Every teenager girls will have an experienced in puberty. Puberty is a period of sexual maturation. In this condition which a girl is experiencing physical changes, hormonal, and sexual and able to conduct the process of reproduction. At the beginning of puberty, it has levels of the hormone LH (Luteinizing Hormone) and FSH (Follicle Stimulating Hormone) will increase. This manner is stimulating the formation of sex hormones. For young women increased levels of these hormones. It causes the maturation of the breast, ovary, uterus, vagina, and the start of the menstrual cycle. In addition, it is also the emergence of secondary sexual characteristics, such as the growth of pubic hair and underarm hair (Kharuriz, 2009). 
It is nornally, where the young woman ready to undergo, they will have reproductive period. It is called a transition from childhood to the age of maturity, better known as puberty, characterized by menstruation. In generally, the average to reach menarche or early menstruation should be started at age 13 years old (Manuaba, 2010).

So far,most of parents in Aceh think that condition of their daughter no need to be discussed, because this condition is usual happened for young lady. So the lady just talk to her mother only. So that, who has early adolescents lack the knowledge and attitude pretty good about the physical and psychological changes associated menarche, mental readiness is indispensable before menarche because of feelings of anxiety and fear will emerge (Proverawati and Misaroh, 2011).

The girls who do not know their bodies will be changed and reproductive processes. That can be assumed menarche evidence of disease or even punishment for bad behaviour (Laila, 2011). Young girls will have difficulties experience such as excessive anxiety in the face of the first menstruation when previously she had never read or discuss either from peers or with their mother (Lubis, 2011).

Based on the results of the study from Arintha Pratamasari on May 28, 2009. She was an analytical to determine the relationship of knowledge about menstruation with the readiness of girls around puberty the face ofmenarche in SMPN 4 Sleman, Yogyakarta, shows that there was a significant relationship between knowledge of adolescents age of puberty with preparedness in the face of menarche (Pratamasari, January, 2015). The knowledge, thoughts, beliefs, and emotions play an important role to determine the hood intact. Phase arrival of menstruation is a period where truly ready biologically undergo feminine function (Suryani \& Widyasih, 2008).

The results of the initial assessment at Elementry School at Paya Bili against some students in class 5 , on average. They said that have never heard the word menarche in their life before. It's mean, they have no knowledge yet. So, the condition will come to them, as well as signs and symptoms of the menarche.The knowledge about menarcheis neededby young women from that age. It's usual that menarche will come to them because of changes condition of their body from allite girl become a teen. This condition can be informed to them, especially the students who are studying in the grades 5 and 6 at Elementary School. Considering there are still many girls who do not understand about the first menstruation or menarche. So that the research should be done to know the real condition in the field of rural area in North Aceh.

\section{MATERIALS AND METHODS}

\section{A. Types of Research}

This research can be clasified into descriptive which aims to identify the knowledge of menarche for school girls who study at Elementry School State 13 Paya Bili Meurah Mulia district, North Aceh regency year 2015.

\section{B. Sample}

Total population namely 30 people. Their condition to be daughter who still sittinginthe level 5and6 Elementry School State 13 at Paya Bili Meurah Mulia district, North Aceh.

\section{Place and Time Research}

Elementry School State 13 Paya Bili Meurah Mulia district, North Aceh. The data collection is done ranging from 10 to 15 May 2015 by distributing questionnaires to the population that had been prepared previously.

\section{Processing and Data Analysis}

Processing data is done manually by following thestepsas suggested as followedbyediting, coding, and tabulating. The data were analyzed descriptively namely by looking at the percentage of data collected and presented in tabular form frequency picture (Budiarto, 2002).

Formula : $\quad p=\frac{f}{n} \times 100 \%$

Information :

$P \quad$ : percentage

$f \quad$ : frequency

$n \quad:$ number of the population from which the sample 


\section{RESULT AND DISCUSSION}

Table of Distribution What Knowledge Respondents About Menarche At Elementry School State 13 Paya Bili Meurah Mulia District North Aceh

\begin{tabular}{|c|l|c|c|c|}
\hline No & $\begin{array}{c}\text { Respondents } \\
\text { Knowledge } \\
\text { About }\end{array}$ & $\begin{array}{c}\text { Categor } \\
\mathbf{y}\end{array}$ & $\begin{array}{c}\text { Frequen } \\
\text { cy }\end{array}$ & $\begin{array}{c}\text { Percentage } \\
\text { (\%) }\end{array}$ \\
\hline 1 & Menarche & Enough & 20 & 67 \\
\hline 2 & $\begin{array}{l}\text { Definition of } \\
\text { Menarche }\end{array}$ & Good & 28 & 93 \\
\hline 3 & $\begin{array}{l}\text { Factors Affecting } \\
\text { Menarche }\end{array}$ & Less & 25 & 83 \\
\hline 4 & $\begin{array}{l}\text { Disruption } \\
\text { Ahead } \\
\text { of Menarche }\end{array}$ & Enough & 18 & 60 \\
\hline 5 & $\begin{array}{l}\text { How To } \\
\text { Overcome } \\
\text { Disorders } \\
\text { Menarche }\end{array}$ & Less & 12 & 40 \\
\hline
\end{tabular}

The results showed that the knowledge about the menarche from the school girls who study at Elementry School State 13 at Paya Bili Meurah Mulia in 2015 still. They can be catagorized better. It is not as expected, eventhough they never get information from their school about menarche, but the information is still very minimal and not yet fully understood. For average have never heard of what does mean menarche,and when it will come, as well assigns and symptoms menarche. They sometimes hear from their friend who older then them, but the information they receive still not clear.

According to (Proverawati and Misaroh, 2011) which states that during this time some people thing that taboo to discuse about menstruation in their family, so that early adolescents lack the knowledge and attitude pretty good about the physical and psychological changes associated menarche. Readiness mentally very required before menarche because of feelings of anxiety and worry when it will appear.

Teenager girls needs more information on the process of menstruation and health during menstruation, they will have difficulty in controling with first menstrual if previously she has never read or discussed either from peers or with their mother. Not a few teenagers who do not know about menstruation, so it will affect the youth in running the maturity period.

Menarche may cause negative or positive reactions for the young girls. If they are already prepared and informed of impending menstruation then they will not experience anxiety and other negative reactions, but if they are not well-informed it will experience negative (Soetjiningsih, 2007). Psychoanalytic observation, that there are certain psychic reactions during the first period and then raised a process called by dr. Helena Deutsch as "Castration Complex" or genital trauma. At some events complex castration or traumatized genitalia that appears different picture fantasy weird accompanied by anxiety and fears that are not real, accompanied by feelings of guilt, which are associated with bleeding problems of the genital organs and processes of period (Suryani and Widyasih, 2008).

\section{CONCLUSIONS}

The results showed that the knowledge about menarche at Elementry School State 13 Paya Bili Meurah Mulia district, North Aceh 2015. That can be concluded more dominant in the category enough. The details are as follows:

1. Knowledge about understanding girls menarche more dominant in either category.

2. Knowledge of young women about the factors affecting menarche more dominant in the category of less.

3. Knowledge teenage girls about the change and disturbance just before menarche more dominant in the category enough.

4. Knowledge of young women on how to resolve distrurbance at menarche more dominant in the category of less.

\section{REFERENCES}

BKKBN. (2011). Kesehatan Reproduksi Remaja. http://prov.bkkbn.co.id.

Budiarto. E. (2002). Dasar - Dasar Metode Statistika Kedokteran. EGC. Jakarta.

Kharuriz. (2009). Proses Terjadinya Menstruasi. http://diarykiranti.com/2009/06/bagaim ana-proses-terjadinya-menstruasi. Accessed January 2015.

Laila. (2011). Buku Pintar Menstruasi. Buku Biru. Jogjakarta.

Lubis. (2011). Gambaran Pengetahuan Remaja Putri Tentang Menstruasi. http://ktiakbid.lubis.com/2011/05/kti-gambaranpengetahuan-remaja-putri. Accessed \anuary 2015 
Manuaba. I. G. (2010). Memahami Kesehatan Reproduksi Wanita. Arcan. Jakarta.

Pratamasari, A. Hubungan Pengetahuan Tentang Menstruasi dengan Kesiapan Remaja Putri Usia Pubertas Menghadapi Menarche Di SMPN 4 Yogyakarta. www.medicine.uii.ac.id Accessed January 2015.

Proverawati and Misaroh. (2011). Menarche: Menstruasi Pertama yang Penuh Makna. Muha Medika, Yogyakarta. 2011.

Suryani. E and Widyasih. H. (2008). Psikologi Ibu dan Anak. Fitramaya. Yogyakarta.

Soetjiningsih. (2007). Tumbuh Kembang Remaja dan Permasalahannya. Sagung Seto. Jakarta.

Widyastuti, et al. (2009). Kesehatan Reproduksi. Fitramaya. Yogyakarta. 